\title{
Nursing students in the community: entrepreneurial strategy and proponent of changes
}

\author{
Acadêmicos de enfermagem na comunidade: estratégia empreendedora e propositora de mudanças \\ Académicos de enfermería en la comunidad: estrategia emprendedora y proponente de cambios
}

\section{Dirce Stein Backes', Bethânia Kraemer Haag', Janine Vasconcelos', Camila Biazus Dalcin", Marli Terezinha Stein Backes", Lurdes Lomba"'}

\author{
'Centro Universitário Franciscano. Santa Maria, Rio Grande do Sul, Brazil. \\ "Universidade Federal de Santa Catarina. Florianópolis, Santa Catarina, Brazil. \\ III Escola Superior de Enfermagem de Coimbra. Coimbra, Portugal.
}

\begin{abstract}
How to cite this article:
Backes DS, Haag BK, Vasconcelos J, Dalcin CB, Backes MTS, Lomba L. Nursing students in the community: entrepreneurial strategy and proponent of changes. Rev Bras Enferm [Internet]. 2018;71(Suppl 4):1799-804.

[Thematic issue: Education and teaching in Nursing] DOI: http://dx.doi.org/10.1590/0034-7167-2017-0382
\end{abstract}

\author{
Submission: 06-15-2017 Approval: 01-11-2018
}

\begin{abstract}
Objective: To report the insertion of the nursing students of the Franciscan University Center in the community through the project Adopting a Family, contributing to critical thinking within the Nursing academic production and its articulation to collective health. Results: In the professors' evaluation, the activity represented an effective articulation and insertion of the university in the community; for the students, it allowed for spaces of construction, deconstruction and negotiation with the unknown and the uncertain; for the families, it enabled the feeling of being remembered and valued as human beings and citizens. Through the experiences had, the transformation of health practices goes through the emergence and valuation of new knowledge. Final considerations: The insertion of the university in the community is constituted by an entrepreneurial strategy that is proponent of changes, due to its more effective and resolute outreach of health issues proposed by the national health system.
\end{abstract}

Descriptors: Nursing Formation; Nursing Practice; Nursing; Education; Community-Institution Relations.

\section{RESUMO}

Objetivo: relatar a inserção comunitária dos acadêmicos de enfermagem do Centro Universitário Franciscano, por meio do projeto Adotando uma Família, e contribuir para a reflexão crítica no âmbito da produção acadêmica e sua articulação com a saúde coletiva. Resultados: na avaliação dos docentes, a atividade representou uma efetiva articulação e inserção da universidade na comunidade; para os acadêmicos, possibilitou espaços de construção, desconstrução e negociação com o desconhecido e o incerto; e para as famílias, o sentimento de terem sido lembradas e valorizadas como seres humanos e cidadãos. A transformação das práticas de saúde passa, a partir do vivido, pela emergência e valorização de novos saberes. Considerações finais: a inserção da universidade na comunidade se constitui, portanto, em uma estratégia empreendedora e propositora de mudanças, pelo alcance mais efetivo e resolutivo das questões propostas pelo sistema de saúde nacional.

Descritores: Educação em Enfermagem; Prática de Enfermagem; Enfermagem; Educação; Relações Comunidade-Instituição.

\section{RESUMEN}

Objetivo: relatar la inserción comunitaria de los académicos de enfermería del Centro Universitario Franciscano, a través del proyecto Adotando uma família, y contribuir a la reflexión crítica en el ámbito de la producción académica y su articulación con la salud colectiva. Resultados: en la evaluación de los docentes, la actividad representó una efectiva articulación e inserción de la universidad en la comunidad; para los académicos, posibilitó espacios de construcción, deconstrucción y negociación con lo desconocido y lo incierto; y para las familias, el sentimiento de haber sido recordadas y valoradas como seres humanos y ciudadanos. La transformación de las prácticas de salud pasa, a partir de lo vivido, por la emergencia y valorización de nuevos saberes. Consideraciones finales: la 
inserción de la universidad en la comunidad se constituye, por lo tanto, en una estrategia emprendedora y proponente de cambios, por el alcance más efectivo y resolutivo de las cuestiones propuestas por el sistema de salud nacional.

Descriptores: Educación en Enfermería; Enfermería Práctica; Enfermería; Educación; Relaciones Comunidad-Institución.

\section{CORRESPNDING AUTHORＣamila Biazus DalcinＥ-mail: camilabiazus@hotmail.com}

\section{INTRODUCTION}

The insertion of the university in the community, systematized by inter and multiprofessional actions, constitutes one of the foundations of the Institutional Pedagogical Project of the Franciscan University Center (Unifra). The materialization of this proposal occurs through the development of the basic functions of the institution (teaching, research and extension), permeated and sustained by a concrete diagnosis of social reality ${ }^{(1)}$.

The idea of "insertion of the university in the community" was wisely discussed by Cristovam Buarque in a remarkable text entitled "Uma idéia de Universidade", in which the author sought to articulate the elitist tradition of the university with the depth of his social commitment. For Buarque, university policies must combine the maximum of academic quality with the maximum of social commitment. The author states that this quality is a condition of product valuation that emerges from the university; however, what will lead to the effective use of this academic-borne product is its extensive social commitment, namely, its anti-elitist condition ${ }^{(2)}$.

Based on these premises, Unifra opted for a prospective institutional politics of perception and analysis of trends in society, motivated by collaborative and proximity attitudes between what the institution does and what society expects of it. Such an attitude has three main theoretical foundations: systemic thinking, integral human formation, and community insertion, which legitimizes the prerogative of conceiving the subject/user within their context, as an inextricable part of a network of systemic interactions and relations.

Given the uncertainty and the volatility of social phenomena, the need to train professionals with integral, global and systemic vision emerges in an ever-increasing manner. A formation that is contextualized, able to develop critical spirit, creativity, willingness for innovation, positive, proactive and negotiator attitudes, that is, the ability of learning to know, to do, to coexist and to be $\mathrm{e}^{(3-4)}$.

To do that, it is essential that formative processes that articulate professional formation with the needs and demands of society as a strategy for economic, social and cultural development be developed ${ }^{(4)}$. Consequently, this articulation must occur since graduation or technical education and until the inclusion of the professionals into work, through permanent education.

Despite the many challenges to be faced, huge advances can be seen in the health scenario, mainly those related to the consolidation of SUS. Going this direction, the National Policy of Humanization on Caring and Management from SUS (PNH) is understood as a path favorable to the expansion of access to quality health services and products, the co-responsibility among workers, managers and users in management and care processes, of supporting the construction of collaborative networks among various industries engaged to health production, and emancipation of the subject as the protagonist of his own history. Hence, this initiative has resulted in more dialogic, participatory and integrative management and caring processes of various subjects and sectors committed to the health phenomenon ${ }^{(5-6)}$.

\section{OBJECTIVE}

To report the experience of insertion of the Franciscan University Center in the community through the project Adopting a Family, contributing to critical thinking within the Nursing academic education and their articulation to collective health, based on the aforementioned and considering the importance of the institutional support of the university in the process of consolidation of SUS.

\section{METHOD}

This experience report is related to the project Adopting a Family, which aims to articulate theory to the daily practice of families in situation of social, environmental and socio-economic vulnerability, the process being conducted through the actionresearch method. The project occurs twice a year since the first half of 2009.

To this end, third semester nursing students were organized into teams of four components and encouraged to articulate a nursing theory with the everyday reality of a family. All the students were studying the discipline of Nursing Theories in order to perform the activity, having guidance of a professor who taught classes in that semester and who they already knew. The families were residing in a macro-region of the municipality of Santa Maria (RS), Brazil, wherein Unifra built and maintains a relation of community insertion by means of interdisciplinary practices in health care.

These families were specifically chosen by the Family Health Strategy team (ESF), according to previously established criteria and priorities. Among these priorities were families with history of drug addiction, family violence, child prostitution, chronic diseases and mental disorders. The families, in its majority, were composed of six to eight members, couples (sometimes separated) that kept their livelihood through selective garbage collection, with supplementary income from the Bolsa Família program, an initiative of the country's government. It should be noted that, to this end, the nursing students were properly informed and instructed on the conditions of the families, as well as oriented about the theoretical-practical process that would be the basis of the formation of the bond.

With the objectives of promoting the bond between academic/ professional and user, and incite sensitivity, solidarity and exercise of citizenship, this academic activity was developed by means of periodic visits to the families. Each visit was oriented by a systematized theoretical-practical process, which will be detailed below. The visits, with duration of up to two hours, were performed in groups by means of public transportation. On these occasions, each supervisor accompanied its respective team of nursing students. It should be 
noted that, as the activity advanced, several teams visited their "families" in days other than the ones scheduled, motivated by the illness of some family members or at their requests. Such visits, however, were conducted without the presence of supervisors and were not part of the disciplinary activity proposed. In certain times, more specifically in days of intense rain, cold or in holidays, there were students that, sensitized, invited their own family for a visit to the "adopted family".

The theoretical-practical activity, aside from being based in a nursing theory, was supported by methodological strategies, such as: effective and affective interaction with the family; creation of bonds of trust; and participatory and collective construction from all involved, in order to emancipate the family by strengthening their ability of being protagonists of their own story. Figure 1 shows the structure of the process of the project activities.

The theoretical-practical activity always has the duration of one academic semester, and there have been twelve editions so far, encompassing about a hundred families. With each edition, twelve to fifteen visits were made on average. As an outcome of each semester, there was a moment of fraternization at the local community center, including professors, students, families involved, the ESF team, and community leaders. At that moment, each group of nursing students, along with their guiding professor and the family adopted, were motivated to report the experiences of the semester, which, in most cases, led to feelings of empathy, sensitivity and bond between those involved.

The process was developed and evaluated in the course of the twelve semesters the project occurred by means of monitoring and guidance of students by professors in respect to the visits, through the experience reports in the classroom and in the moments of final integration, based on the families' reports. It is worth mentioning that the statements present in this study are from families from 2008 until 2014, and that the project is still ongoing, due to its impact in the community, where Unifra has been expanding its activities alongside the ESF.

The ethical aspects of the study were observed in accordance with the recommendations of the resolution No. 196/96 of the
National Health Council, which prescribes the ethics in research with human beings in Brazil. The project was approved by the Research Ethics Committee of Unifra.

\section{REPORTING THE EXPERIENCES OF FAMILIES, NURSING STUDENTS AND PROFESSORS}

The guiding and motivating element of this study was characterized by visits of nursing students and professors to families selected by the project, as a technology for the care, teaching and research ${ }^{(7)}$. In daily life, students and professors found themselves with real and, at the same time, contradictory, antagonistic and uncertain situations. These situations were shown to be relevant as experiences crossed over by the process of only visualizing community health contexts in media or books. It was noticed that this enabled the preparation for real situations that future nurses may face in their professional history. Cultural differences, clash of values, and insecurity in the face of the new enabled, aside from contact and dialogue with the concrete reality of the subjects in vulnerable situations, to rethink values and knowledge considered absolute and unquestionable truths. This process can be seen in the statements from families, students and professors (Chart 1).

Chart 1 - Statements from families, students and nursing professors

\begin{tabular}{|c|c|c|}
\hline Statements from families & Statements from students & Statements from professors \\
\hline $\begin{array}{l}\text {...very nice attitude of them, } \\
\text { right, very nice persons, have } \\
\text { no prejudice against us poor } \\
\text { people, right, and they come } \\
\text { visiting... (F1) } \\
\text {...like in the day they arrived, } \\
\text { when I was making little cakes, } \\
\text { they even ate cakes... that I } \\
\text { made... (F2) } \\
\text {...that visit was a pleasure for us } \\
\text { to chat with them, talk to them, } \\
\text { open up to them... (F3) }\end{array}$ & $\begin{array}{l}\text { On the first visit I was very shocked. I got } \\
\text { disappointed and thought I wouldn't do anything. } \\
\text { That house with one room, with a door and a } \\
\text { window and nothing else... It had only a bed, a } \\
\text { stove, an old couch, food, and clothes hanging on } \\
\text { the walls, the floor carpet all wet, the sanitary sewer } \\
\text { ran in front of the house. There live the woman and } \\
\text { six children. But as the visits continued, the mother } \\
\text { and children were able to increase the house a little. } \\
\text { Then we start thinking: how can they live in such } \\
\text { a situation? People complain about so many trivial } \\
\text { things, but then you realize that the children live } \\
\text { happily even without having anything. (E1) }\end{array}$ & $\begin{array}{l}\text { Being a mediator of a theoretical-practical } \\
\text { innovative activity does not seem to be as simple } \\
\text { for the academicized eyes addicted to hegemonic } \\
\text { knowledge, at first glance. Initially, they needed to } \\
\text { rethink values and personal beliefs, questioning the } \\
\text { very practice of being, of thinking on nursing, as well } \\
\text { as to review the very concept of health reduced to } \\
\text { the absence of disease. Accompanying students in } \\
\text { visits to these families, creating affective and effective } \\
\text { bonds, it means to let prejudices aside, to broaden } \\
\text { perspectives, and believe that it is possible to dream } \\
\text { of a more entrepreneurial and transformative practice } \\
\text { of the real needs of the population. (P1) }\end{array}$ \\
\hline
\end{tabular}

To be continued 


\begin{tabular}{|c|c|c|}
\hline Statements from families & Statements from students & Statements from professors \\
\hline $\begin{array}{l}\text { If other universities also had } \\
\text { this bonding link between } \\
\text { the human being and the } \\
\text { professional, yeah, that } \\
\text { there's not much difference, } \\
\text { but the good professional, } \\
\text { he graduates knowing the } \\
\text { reality... So, like, this is highly } \\
\text { positive, A grade for those } \\
\text { students, right... (F5) } \\
\text {...'t would be nice if you could } \\
\text { meet others, you know, to } \\
\text { bring these other people the } \\
\text { same things they made us feel, } \\
\text { you know... It would be nice... } \\
\text { The suggestion would be to } \\
\text { include other families. (F8) } \\
\text {...we talked a lot, about } \\
\text { serious things, about my life, } \\
\text { they got to know a bit of me } \\
\text { and my family and I knew a bit } \\
\text { of each one of them... pretty } \\
\text { cool, pretty natural... (F13) } \\
\text { Those students learning how } \\
\text { to bathe and change the } \\
\text { diaper from those children, } \\
\text { they actually formed a big } \\
\text { family, yeah, the institution } \\
\text { and the family, the family } \\
\text { and the institution... Only } \\
\text { that linking bond the years } \\
\text { won't ever erase remained. As } \\
\text { much as distance separates } \\
\text { these human beings, at that } \\
\text { moment, that one good thing } \\
\text { that happened will remain for } \\
\text { life. (F14) } \\
\text {...we chat with them, talk to } \\
\text { them, we open ourselves up } \\
\text { to them, even myself, I have... } \\
\text { like... well, I managed to open } \\
\text { up so much to them, I got some } \\
\text { fondness for those girls, you } \\
\text { know, all honesty, I opened } \\
\text { myself up to them... (F16) } \\
\text { That affection they have with } \\
\text { us, that you have with us here. } \\
\text { You come from there... there } \\
\text { on the other side, to hear our... } \\
\text { how do I say it, our problems, } \\
\text { the attention you give us. (F20) }\end{array}$ & 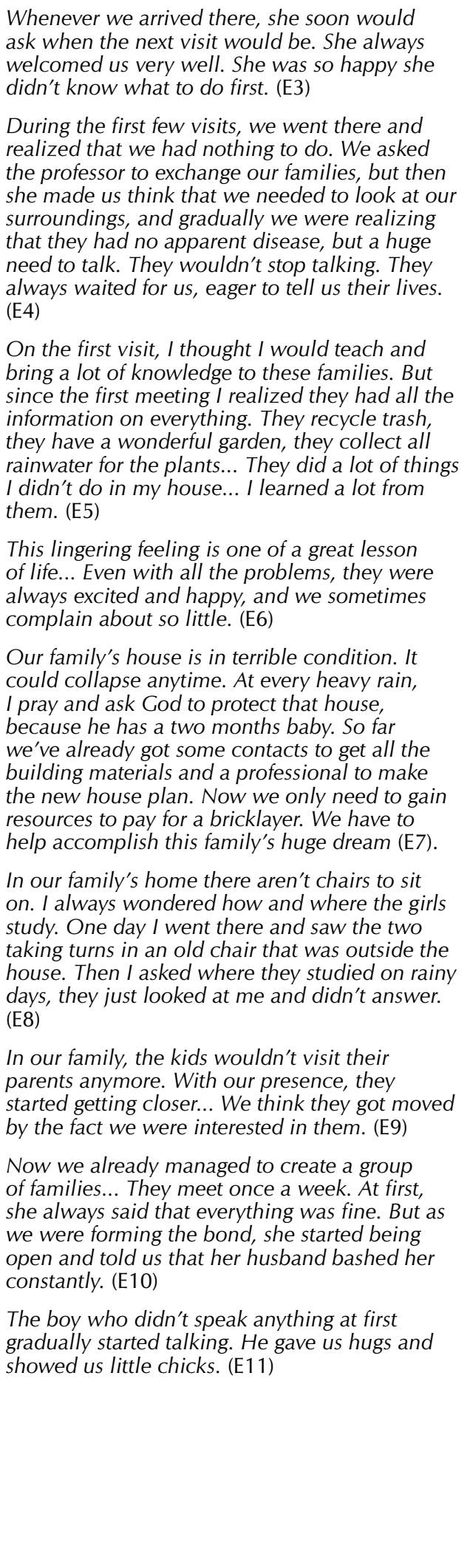 & $\begin{array}{l}\text { Sometimes I felt confused and insecure, } \\
\text { especially when faced with conflict situations } \\
\text { - family fights or between neighbors... It wasn't } \\
\text { clear how to conduct those complex situations } \\
\text { with the students. (P2) } \\
\text { Accompanying students to home visits, we had } \\
\text { the opportunity to experience a reality until } \\
\text { then very distant from our daily lives. To rethink } \\
\text { values, observe cultures and formations different } \\
\text { from ours instigated us to re-examine the } \\
\text { concepts we had up to that time. The nursing } \\
\text { practice must be present in all social and } \\
\text { cultural contexts, acting on behalf of the human } \\
\text { being. (P3) } \\
\text { This process transcended from the academic } \\
\text { daily life to the cultural and social through } \\
\text { dialogue with different knowledge [...] enabling } \\
\text { an ethical rethinking, based on the autonomy of } \\
\text { the subjects. (P4) } \\
\text { The role of the professor as facilitator of actions } \\
\text { in the community needs to be in accordance } \\
\text { with the structural conditions, the culture, the } \\
\text { values, the accessibility to health services, and } \\
\text { the basic mechanisms of life in society, in order } \\
\text { to instigate the different. These kinds of action, } \\
\text { which lead students to experience the reality } \\
\text { of health determinants, large and complex, } \\
\text { becomes more challenging when health care is } \\
\text { directed to the families subjected to numerous } \\
\text { vulnerabilities... (P5) } \\
\text { I never thought our presence would be so } \\
\text { significant. I remember I asked our family's } \\
\text { mother, } 24 \text { years old, if she was thinking about } \\
\text { continuing education. She told me that she } \\
\text { couldn't, because of her small children... but on } \\
\text { the next visit she soon told us she had looked on } \\
\text { the possibility of continuing her studies. Soon I } \\
\text { remembered the importance of our talking and } \\
\text { presence. She felt instigated. (P7) } \\
\text { At the beginning, we felt like our hands were } \\
\text { tied... We got frustrated many times. We thought } \\
\text { our visits were useless. But in the end, when we } \\
\text { thought about it, we realized the transformations } \\
\text { that had occurred. (P8) }\end{array}$ \\
\hline
\end{tabular}




\begin{tabular}{|c|c|c|}
\hline Statements from families & Statements from students & Statements from professors \\
\hline \multicolumn{3}{|l|}{$\begin{array}{l}\text {...they were already part of } \\
\text { my family... The children said: } \\
\text { 'Hey, mom, your daughters } \\
\text { are coming...' (F31) }\end{array}$} \\
\hline \multicolumn{3}{|l|}{$\begin{array}{l}\text {...until now I like them, I miss } \\
\text { them. We cried. We miss } \\
\text { them... I wish they would } \\
\text { come back. (F39) }\end{array}$} \\
\hline \multicolumn{3}{|l|}{$\begin{array}{l}\text { Look, I tell you, I miss it... It's } \\
\text { been a while since they last } \\
\text { came, right, and I'm missing } \\
\text { them now, you know, that } \\
\text { day-to-day contact. (F43) }\end{array}$} \\
\hline \multicolumn{3}{|l|}{$\begin{array}{l}\text { Look, wish they be very } \\
\text { happy, thank you very much } \\
\text { for what they did for us. (F54) }\end{array}$} \\
\hline $\begin{array}{l}\text { We have to be patient, } \\
\text { right, because problems, } \\
\text { everyone has them, we have } \\
\text { to be patient and the solution } \\
\text { will come. No matter how } \\
\text { difficult, no matter how } \\
\text { complicated it is, we always } \\
\text { reach a solution. Nothing is } \\
\text { impossible! If we fight, persist, } \\
\text { move forward, we achieve } \\
\text { everything. I understood it } \\
\text { more or less like that. (F72) }\end{array}$ & & \\
\hline
\end{tabular}

The theoretical-practical activity developed with the "adopted families", an innovative and entrepreneurial activity, made it possible to rethink the method of teaching and learning, as well as create and expand the concept of health by valuing the bond between professional and user, and of the nursing care ${ }^{(4,8)}$. In the professors' evaluation, the activity represented an effective articulation and insertion of the university in the community, i.e. the possibility of a new proposal and the certainty of a health system more effective and efficient. From the point of view of students, the activity allowed for spaces of construction, deconstruction and negotiation with the unknown and the uncertain. For the families, the feeling of being remembered and valued as human beings and citizens.

Through these experiences, the transformation of health practices goes through the emergence and valuation of new knowledge, among them popular knowledge; a dialogical attitude between professional and user; a conceptual and scientific openness in relation to the existing biomedical model; and greater political and ideological responsibility of managers. These transformations are potential bond constructors, approximating who offers care to those who receive it, originating from solidarity attitudes that imply putting oneself in the other person's level and letting them be themselves.

\section{UNIVERSITY: SPACE FOR MEETING OF KNOWLEDGE AND PROPONENT OF CHANGES}

The university should be a space, par excellence, for meeting, constructing and being open to different and new knowledge. Being open to the other is the most deep meaning of the democratization of the access to university and of permanence in it. In a society where quantity and quality of life are based on increasingly complex configurations of knowledge, the university is only legitimate when meeting extension activities, with integral research and training activities ${ }^{(2)}$.

Therefore, it is imperative that the university allows for spaces of interaction with the community in order to identify key research issues and, from then on, define intervention priorities. The systematization of this extension process, developed cooperatively, must pay attention to ethical and citizenship performance, to analysis of impacts and perverse effects and, in particular, to contextualized and dialogical learning, based in new and different practices and knowledge.

The university is the institution that is able to better assume the role of a social entrepreneur in contemporary society whose success lies in the ability to do things differently, acquiring value and social capital with the ability to articulate and democratize theoretical-practical knowledge ${ }^{(4)}$. With the increased social complexity and interdependence between the various social subsystems, the risks and costs of social innovation will be increasingly higher, demanding proponent and innovative social projects in their way of thinking and acting both individually and collectively.

Corroborates with this idea ${ }^{(4,8)}$ the argument of the entrepreneurial potential of the university, when highlighted its autonomy and the fact of having relatively distanced mechanisms of market pressures and increasing social rigidity. The university needs to promote political coalitions with groups and organizations where the memory of innovation is still present, allowing for the democratization of society. Violating the conventional order that extension/insertion of the university comes from teaching and research, the institutional concept of Unifra is that extension is configured as a process that brings the university both 
problems and knowledge generated in the most varied segments of reality. This is an interactive and educational process comprising a conception of university as facing reality, with the aim of intervening in this reality through research and rekindle the process of teaching in the formation of nurses ${ }^{(3-4)}$.

A major coalition to be strengthened and encouraged in this context of discussions is related to the institutional support in SUS, guided by principles and guidelines that stand out as the largest and most innovative systems in the world. Its innovative nature is expressed primarily through an extended conception of health, by means of a gradual overcoming of the biological model centered on the disease, and the strong impact on the promotion and protection of health ${ }^{(5,7)}$.

In this process of construction and consolidation of SUS, the university constitutes an important space of encounter between knowledge, construction and/or reconstruction of theoreticalpractical scenarios, and a creative space that proposes changes in cultural, social and economical contexts. Thus, it is important that the academic community develops educational processes that articulate the professional formation of nurses with the needs and demands of society.

\section{FINAL CONSIDERATIONS}

The theoretical-practical educational process of nursing inserted in the reality of families and communities constitutes an important initiative for the construction of a culture focused on the fundamental rights of the human person, open to differences and oriented towards the interests and needs of all citizens. However, rather than creating a new proposal, it is needed to re-signify and re-organize knowledge, knowing, doing, coexisting and being, based on new referentials capable of creating favorable educational spaces for the construction of thinking, sympathetic subjects committed towards citizenship and social well-being.

This insertion of the university in the community seeks, although in a context of contradiction and uncertainty, to understand the intimate connection between research and extension, producing a real movement for change in academic formation, overcoming the critical dissociation between university and reality.

Therefore, the insertion of the university in the community is constituted of an entrepreneurial strategy that is proponent of changes, due to its more effective and resolute outreach of health issues proposed by SUS. Hence, as a democratization strategy of management practices and care in SUS, the insertion of the university in the community enables, above all, re-signification and organization of knowledge, of knowing, of doing, of coexisting and of being, based in new referentials, by promoting educational spaces favorable to the construction of thinking, critical, sympathetic subjects committed to citizenship and social well-being.

\section{ACKNOWLEDGMENTS}

We thank the National Council for Scientific and Technological Development (CNPQ) for their support to the project "O cuidado de enfermagem como prática socialmente empreendedora", Process No. 302103/2017-1.

\section{REFERENCES}

1. Centro Universitário Franciscano. Projeto Pedagógico Institucional [Internet]. 2012 [cited 2017 Jan 22]. Available from: https:// slidex.tips/download/enfermagem-projeto-pedagogico\#modals

2. Santos BS. Para um novo senso comum: a ciência, o direito e a política na transição paradigmática. 8a ed. São Paulo (SP): Cortez; 2011.

3. Fernandes JD, Reboucas LC. A decade of national curriculum guidelines for Graduation in Nursing: advances and challenges Rev Bras Enferm [Internet]. 2013 [cited 2017 May 15];66(spe):95-101. Available from: http://www.scielo.br/pdf/reben/v66nspe/ v66nspea13.pdf

4. Stein-Backes D, Stein-Backes M, Lorenzini-Erdmann A, Büscher A, Salazar-Maya AM. Significance of the Nurse's social practice with and through the Unified Brazilian Health Care System. Aquichán [Internet]. 2014 [cited 2017 May 15];14(4):560-570. Available from: http://www.redalyc.org/pdf/741/74133057010.pdf

5. Brasil. Ministério da Saúde. Política Nacional de Humanização. HumanizaSUS [Internet]. Brasília (DF): Ministério da Saúde; 2013 [cited 2016 Sep 5]. Available from: http://bvsms.saude.gov.br/bvs/publicacoes/politica_nacional_humanizacao_pnh_folheto.pdf

6. Barbosa GC, Meneguim S, Lima SAM, Moreno V. National Policy of Humanization and education of health care professionals: integrative review. Rev Bras Enferm [Internet]. 2013 [cited 2017 Jun 15];66(1):123-127. Available from: http://www.scielo.br/pdf/ reben/v66n1/v66n1a19.pdf

7. Romanholi RMZ, Cyrino EG. Home visits in doctors' training: from conception to the challenge of practice. Interface [Internet]. 2012 [cited 2017 Jun 15];16(42):693-705. Available from: http://www.scielo.br/pdf/icse/v16n42/v16n42a09.pdf

8. Dalcin CB, Backes DS, Dotto JI, Souza MHT, Moreschi C, Büscher A. Social determinants of health that influence the healthy living process in a vulnerable community. Rev enferm UFPE on line [Internet]. 2016 [cited 2017 May 2];10(6):1963-70. Available from: http://www.revista.ufpe.br/revistaenfermagem/index.php/revista/article/view/7044/pdf_10313 